\title{
RENTOWNOŚĆ POLSKICH SPÓŁEK PUBLICZNYCH NOTOWANYCH NA WARSZAWSKIEJ GIELDZIE PAPIERÓW WARTOŚCIOWYCH - ANALIZA SEKTOROWA
}

\section{Wstęp}

Kryzys finansowy, który rozpoczął się w roku 2007 na amerykańskim rynku kredytów hipotecznych, doprowadził do dramatycznego załamania aktywności gospodarczej na świecie. Było to jedno z najpoważniejszych załamań od czasów Wielkiego Kryzysu z lat 30. ubiegłego wieku'. Źródeł światowego kryzysu finansowego można doszukiwać się na rynku amerykańskim i tkwią one przede wszystkim w sektorze usług finansowych. Wymienić należy wśród nich m.in.: „błędy polityki makroekonomicznej, w tym przede wszystkim nadmiernie ekspansywną politykę monetarną w Stanach Zjednoczonych, brak właściwego nadzoru instytucjonalnego nad sektorem finansowym, dynamiczny rozwój $>$ innowacji finansowych $<-$ nowych, skomplikowanych, obarczonych wysokim ryzykiem instrumentów finansowych, nieskuteczność działania agencji ratingów kredytowych, dążenie instytucji finansowych, posiadających niską adekwatność kapitałową, do maksymalizacji wyników krótkookresowych poprzez podejmowanie nadmiernego ryzyka"2. Pomimo że jego źródła znajdowały się na rynku amerykańskim, to skutki kryzysu finansowego były odczuwalne również i w Polsce. Inwestorzy zagraniczni negatywnie postrzegali aktywa finansowe krajów rozwijających się i preferowali aktywa o największej płynności czy wiarygodności kredytowej ${ }^{3}$.

W obecnej rzeczywistości gospodarczej, naznaczonej przez kryzys finansowy, zagadnienie rentowności nabiera nowego znaczenia. Inwestorzy ze szczególną uwagą monitorują dokonania jednostek wyrażone przez rentowność. Przyznać należy, że sprawozdawczość finansowa, za sprawą kryzysu, wzmocniła swoją rolę, polegającą na dostarczaniu kluczowych z punktu widzenia funkcjonowania jednostki informacji. Stało się tak mimo oczywistych słabości

\footnotetext{
'Doktorantka, Katedra Ekonomii Instytucjonalnej, Wydział Ekonomiczno-Socjologiczny UŁ.

${ }^{1}$ M. Konopoczak, R. Sieradzki, M. Wiernicki, Kryzys na światowych rynkach finansowych - wplyw na rynek finansowy w Polsce oraz implikacje dla sektora realnego, „Bank i Kredyt” 2010, nr 41 (6), s. 45.

${ }^{2}$ P. Urbanek, Kryzys finansowy a polityka wynagradzania menedżerów, [w:] P. Urbanek (red.), Nadzór korporacyjny w warunkach kryzysu gospodarczego, Wyd. UŁ, Łódź 2010, s. 83-84.

${ }^{3}$ M. Konopoczak, R. Sieradzki, M. Wiernicki, Kryzys..., s. 45.
} 
sprawozdawczości finansowej, polegających zwłaszcza na przedstawianiu głównie informacji historycznych (ex post) czy nieprezentowaniu informacji na temat kapitału intelektualnego. Na rynku kapitałowym nie istnieje jednak alternatywne w stosunku do sprawozdawczości finansowej źródło informacji. Ten szczególny atrybut sprawozdawczość owa uzyskuje m.in. dzięki potwierdzaniu jej wiarygodności przez biegłych rewidentów.

Problem rentowności jest niezwykle istotny z punktu widzenia spółek publicznych. „W Polsce status spółki publicznej może posiadać spółka akcyjna lub spółka komandytowo-akcyjna. W praktyce publicznymi są tylko spółki akcyjne”״. Jak zaznacza się w literaturze, „spółka akcyjna jest najbliższą ideału formą prowadzenia działalności gospodarczej. [...] Przyznać również należy, że zakres i jakość ujawnianych przez spółki publiczne informacji, w tym informacji o charakterze finansowym, jest największa"s. Co ważne, sprawozdawczość finansowa jest fundamentalnym składnikiem raportów okresowych ujawnianych przez spółki publiczne.

Celem pracy jest dokonanie wielopłaszczyznowej analizy rentowności spółek publicznych działających na GPW, z uwzględnieniem sektorów działalności. Grupę badawczą stanowiły spółki publiczne notowane na Warszawskiej Giełdzie Papierów Wartościowych, wchodzące w skład następujących sektorów: budownictwo, informatyka, przemysł elektromaszynowy, przemysł spożywczy, media, handel hurtowy i handel detaliczny. Do badania zostały wykorzystane informacje z raportów rocznych spółek publicznych (przede wszystkim sprawozdań finansowych), które są publikowane na stronach internetowych poszczególnych spółek. Metodą badawczą zastosowaną w niniejszym badaniu była analiza danych ujawnianych przez spółki publiczne wchodzące w skład omawianej grupy. Artykuł ma charakter teoretyczno-empiryczny.

\section{Rentowność w literaturze przedmiotu}

Jednym $\mathrm{z}$ podstawowych celów działalności przedsiębiorstwa, przede wszystkim prywatnego, jest maksymalizacja zysku. Aby zmierzyć stopień realizacji tego zadania należy dokonać oceny efektywności gospodarowania, która ma swoje odzwierciedlenie $\mathrm{w}$ rentowności ${ }^{6}$.

Rentowność jest istotnym aspektem z punktu widzenia właścicieli przedsiębiorstwa. Dzięki pomiarowi zyskowności jednostki gospodarczej mogą oni uzyskać odpowiedź, czy zaangażowanie kapitału własnego w przedsiębiorstwo było opłacalne i ma swoje odzwierciedlenie w wielkości zysku, czy też było

\footnotetext{
${ }^{4}$ J. Gad, Rachunkowość w procesie nadzoru w spótkach publicznych, Wyd. UŁ, Łódź 2011, s. 10.

${ }^{5}$ Ibidem, s. 11.

${ }^{6}$ K. Stępień, Rentowność a wyplacalność przedsiębiorstw, Difin, Warszawa 2008, s. 23.
} 
złym wyborem i lepiej byłoby zainwestować środki w inny sposób, np. lokując kapitał w banku?

Jedną z metod pomiaru rentowności jest klasyczna wskaźnikowa analiza finansowa. Mierniki należące do tej kategorii wykorzystują różne rodzaje $\mathrm{zysku}^{8}$, które są odnoszone do odmiennych podstaw. To właśnie podstawa odniesienia zysku stanowi fundamentalne kryterium rozróżnienia wskaźników rentowności. Wyróżnia się?:

- rentowność sprzedaży (tzw. rentowność handlowa),

- rentowność majątku (tzw. rentowność ekonomiczna),

- rentowność zaangażowanych kapitałów (tzw. rentowność finansowa).

Powyższe wskaźniki należą do najczęściej stosowanych wskaźników efektywności i opłacalności funkcjonowania przedsiębiorstwa. Przedstawiają one zdolność podmiotu gospodarczego do generowania zysku. Mierniki te pozwalają przede wszystkim odpowiedzieć na poniższe pytania ${ }^{10}$ :

1. Jak opłacalna jest sprzedaż produktów, które są efektem pracy określonej jednostki?

2. Jakie korzyści uzyskuje jednostka angażując w działalność własne zasoby majątkowe?

3. Jaki zwrot uzyskuje jednostka poprzez zainwestowanie swoich kapitałów w działalność gospodarczą?

Uzyskanie odpowiedzi na powyższe pytania ma ogromne znaczenie przy ocenie rezultatów funkcjonowania przedsiębiorstwa, a także przy wyznaczaniu jego perspektyw na przyszłość.

„Wskaźniki rentowności dostarczają informacji, w jaki sposób zarządzanie majątkiem, finansowanie działalności firmy, rozwiązywanie problemów dotyczących płynności finansowej wpływa na rezultaty osiągane przez jednostkę gospodarczą" ${ }^{11}$. Dla obliczenia odpowiednich mierników rentowności niezbędne jest pozyskanie informacji pochodzących ze sprawozdań finansowych. Rysunek 1 przedstawia źródła informacji z poszczególnych składników sprawozdań niezbędnych do obliczenia klasycznych wskaźników rentowności danego przedsiębiorstwa.

${ }^{7}$ Ibidem, s. 36.

${ }^{8}$ Do obliczenia rentowności można zastosować różne kategorie wyniku finansowego, m.in. wynik finansowy netto, wynik finansowy brutto, wynik z działalności gospodarczej, wynik z działalności operacyjnej lub wynik ze sprzedaży. Każdy z tych rodzajów zysku przedstawia inny obszar działalności przedsiębiorstwa. Najczęściej stosuje się jednak wynik finansowy netto, gdyż wielkość ta odnosi się do rentowności całej działalności gospodarczej danego podmiotu i przedstawia ostateczną wielkość kapitału wypracowanego w danym okresie rozliczeniowym przez przedsiębiorstwo.

${ }^{9}$ W. Gabrusewicz, Podstawy analizy finansowej, PWE, Warszawa 2002, s. 208.

${ }^{10}$ E. Nowak, Analiza sprawozdań finansowych, PWE, Warszawa 2008, s. 178.

${ }^{11}$ L. Kopczyńska, Analiza sytuacji majątkowo-finansowej przedsiębiorstwa, [w:] E. Walińska (red.), Meritum. Rachunkowość. Rachunkowość i sprawozdawczość finansowa, Wolters Kluwer business, Warszawa 2007, s. 1323. 


\section{Bilans}

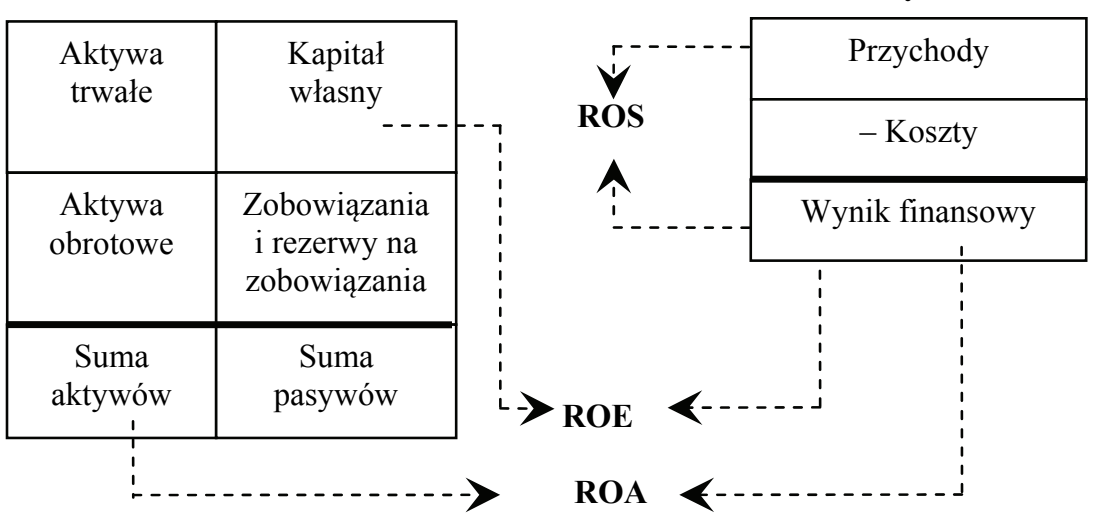

Rysunek 1. Wybrane wskaźniki rentowności a sprawozdania finansowe Źródło: oprac. Własne.

Wskaźnikiem, który zostanie zaprezentowany w pierwszej kolejności, jest rentowność sprzedaży, tzw. ROS (ang. Return on Sale). W literaturze miernik ten jest również nazywany wskaźnikiem zwrotu ze sprzedaży ${ }^{12}$ lub marżą netto ${ }^{13}$ (czy też marżą zysku netto). Można go przedstawić za pomocą relacji wyniku finansowego netto i przychodów ze sprzedaży. Do obliczenia powyższego wskaźnika należy pozyskać informacje, które znajdują się w rachunku zysków i strat (rysunek 1). W mianowniku znajdują się przychody ze sprzedaży produktów, towarów i materiałów.

Wskaźnik ROS informuje o udziale zysku netto w wartości sprzedaży. Im ten wskaźnik jest niższy, tym większa wartość sprzedaży musi być realizowana dla osiągnięcia określonej kwoty zysku ${ }^{14}$. Im wyższy poziom wskaźnika, tym sytuacja jest korzystniejsza, gdyż wyższa jest efektywność osiągniętych przychodów. Przedsiębiorstwo, które osiągnęło wyższy poziom wskaźnika, ma większe możliwości przetrwania, jeśli nastąpi obniżka cen na sprzedawane produkty lub nieprzewidziany wzrost kosztów ${ }^{15}$. Ponadto, wyższy poziom rentowności sprzedaży jest również korzystny dla udziałowców i akcjonariuszy.

${ }^{12}$ K. Stępień, Rentowność..., s. 94

${ }^{13}$ K. Berman, J. Knight, J. Case, Inteligencja finansowa. Co kryja liczby. Przewodnik menedżera, Helion, Gliwice 2007, s. 255.

${ }^{14}$ M. Sierpińska, Analiza sytuacji finansowej przedsiębiorstwa, [w:] M. Sierpińska, T. Jachna (red.), Metody podejmowania decyzji finansowych. Analiza przykładów i przypadków, Wyd. Nauk. PWN, Warszawa 2007, s. 102.

${ }^{15}$ L. Kopczyńska, Tradycyjne metody analizy rentowności, [w:] E. Walińska (red.), Meritum. Rachunkowość. Rachunkowość i sprawozdawczość finansowa 2006, Dom Wydawniczy, Warszawa 2006, s. 524. 
Nie istnieje optymalna wartość tego miernika, a jego poziom zależy od profilu działalności przedsiębiorstwa. W jednostkach gospodarczych, które charakteryzują się dłuższym cyklem produkcyjnym, wymagana jest wyższa zyskowność. Wynika to z faktu ponoszenia wyższych kosztów związanych z zamrożeniem środków, a ponadto ponoszeniem większego ryzyka. Dopuszcza się niższą zyskowność w podmiotach gospodarczych wytwarzających wyroby o krótkim cyklu produkcyjnym i łatwiejszej ich sprzedaży. Z tej też przyczyny wskaźnik danego podmiotu gospodarczego powinno się porównywać z jednostkami, które charakteryzują się podobnym profilem działalności ${ }^{16}$. Ponadto, chcąc uzyskać lepszy obraz efektywności funkcjonowania przedsiębiorstwa pod względem sprzedaży, należy dokonać porównania tego wskaźnika ze wskaźnikami z lat poprzednich.

Kolejnym wskaźnikiem z obszaru klasycznej analizy rentowności jest miernik rentowności majątku, tzw. ROA (ang. Return on Assets). Miernik ten jest również nazywany stopą zwrotu $\mathrm{z}$ aktywów ${ }^{17} \mathrm{i}$ wyrażany stosunkiem wyniku finansowego netto do przeciętnego poziomu aktywów. W celu obliczenia jego wartości niezbędne są informacje pochodzące zarówno z bilansu, jak i rachunku zysków oraz strat (rysunek 1).

Wskaźnik rentowności ROA określa zyskowność aktywów przedsiębiorstwa $\mathrm{i}$ informuje o wysokości zysku netto, który przypada na jednostkę zaangażowanego majątku. Informuje zatem o ogólnej zdolności aktywów jednostki gospodarczej do generowania zysku ${ }^{18}$. Miernik zyskowności aktywów stymuluje eliminację zbędnych i nadmiernych zapasów oraz środków trwałych ${ }^{19}$, poprzez sprzedaż nieprzydatnych środków trwałych, a także likwidację niepotrzebnych zapasów.

W przypadku miernika ROA również nie istnieje jego optymalny poziom. Oczekuje się wzrostu tego wskaźnika z roku na rok. Niemniej jednak nie zawsze jego polepszenie się można interpretować pozytywnie. Wzrost może być spowodowany np. spadkiem aktywów, które są związane ze sprzedażą majątku. Zwiększenie stopy zwrotu $\mathrm{z}$ aktywów może być również podyktowane znacznymi odpisami amortyzacyjnymi lub odpisami aktualizującymi wartość środków trwałych. Zatem poprawa nie jest następstwem polepszenia sytuacji danego przedsiębiorstwa, ale wynika z zapisów księgowych. Ponadto, wielkość wskaź-

${ }^{16}$ L. Kopczyńska, Ocena kondycji finansowej przedsiębiorstwa, [w:] W. Walczak (red.), Analiza finansowa $w$ zarządzaniu wspótczesnym przedsiębiorstwem, Difin, Warszawa 2007, s. $375-376$.

${ }^{17}$ A. Ćwiąkała-Małys, W. Nowak, Zarys metodologiczny analizy finansowej, Wyd. UWr, Wrocław 2005, s. 112.

${ }^{18}$ M. Dynus, B. Kołosowska, P. Prewysz-Kwitno, Analiza finansowa przedsiębiorstwa, TNOiK, Toruń 2005, s. 88.

${ }^{19}$ L. Bednarski, Analiza sytuacji majątkowo-finansowej przedsiębiorstwa, [w:] E. Walińska (red.), Meritum. Rachunkowość..., Warszawa 2007, s. 108. 
nika ROA jest większa dla jednostek gospodarczych, które mają zamortyzowany majątek. Wskaźnik ten jest odpowiednio niższy w przypadku przedsiębiorstw dysponujących nowym, niezamortyzowanym majątkiem.

Rodzaj prowadzonej działalności ma wpływ na wysokość miernika rentowności aktywów. Niska wartość wskaźnika jest charakterystyczna dla branży kapitałochłonnych, natomiast $\mathrm{w}$ branżach niewymagających wysokiego poziomu majątku bywa on znacznie wyższy. Porównanie wysokości stopy zwrotu $\mathrm{z}$ majątku danego przedsiębiorstwa na tle przedsiębiorstw funkcjonujących $\mathrm{w}$ tej samej branży i uzyskanie niskiego poziomu w stosunku do konkurentów może oznaczać, że niewykorzystywane są w pełni moce wytwórcze danej jednostki. Rentowność jednostki jest bardzo istotna $\mathrm{z}$ punktu widzenia kredytodawców danego podmiotu gospodarczego, gdyż informuje o zdolności do spłaty rat i odsetek kredytowych ${ }^{20}$.

Dodatkowo warto również zwrócić uwagę, iż porównując wysokość opisywanego wskaźnika w czasie, tzn. względem poprzednich okresów, widzimy, że może on niekiedy przejawiać duże wahania, które są następstwem zmian zachodzących $\mathrm{w}$ majątku ${ }^{21}$. W związku $\mathrm{z}$ tym zysk dotyczy pewnego okresu, w którym został wygenerowany, natomiast wysokość majątku jest wielkością zmienną w danym czasie. Na wielkość aktywów mają wpływ wszelkie procesy inwestycyjne, dzięki którym przedsiębiorstwo zyskuje nowe środki trwałe (następuje zwiększenie majątku), a także likwidacje zbędnych składników majątku i odpisy amortyzacyjne (następuje w tej sytuacji zmniejszenie sumy aktywów).

Analiza rentowności kapitałów własnych jest kolejnym obszarem klasycznej analizy rentowności. Wskaźnik rentowności kapitalów własnych, tzw. ROE (ang. Return on Equity), określany jest również stopą zwrotu kapitału własnego $^{22}$. Przedstawia on relację między wynikiem finansowym netto a kapitałem własnym.

Dla obliczenia wartości wskaźnika zyskowności kapitału własnego niezbędne są informacje pochodzące $\mathrm{z}$ rachunku zysków i strat oraz bilansu (por. rysunek 1). Efekt finansowy netto należy odczytać, podobnie jak w przypadku ROS i ROA, z rachunku wyników, natomiast wartość mianownika, czyli przeciętną wartość kapitału własnego, należy uzyskać z bilansu. Nie można obliczać wartości wskaźnika ROE w przypadku ujemnego kapitału własnego, bez względu na to, czy przedsiębiorstwo osiąga zysk, czy też notuje stratę. Miernik rentowności kapitałów własnych określa wielkość zysku netto, która przypada na jednostkę (np. zł) zaangażowanych kapitałów własnych. Wartość ROE, w przeciwieństwie do ROA, przedstawia efektywność nie całości kapitału

\footnotetext{
${ }^{20}$ L. Kopczyńska, Ocena..., s. 376.

${ }^{21}$ K. Stępień, Rentowność..., s. 97-98.

${ }^{22}$ L. Kopczyńska, Ocena..., s. 377.
} 
ulokowanego w aktywach trwałych i obrotowych, lecz wyłącznie jego część pomijającą kapitał obcy, czyli zobowiązania długo- i krótkoterminowe ${ }^{23}$. Prezentuje on wielkość zysku z jednostki kapitału, dlatego też poziom tego wskaźnika jest istotny z punktu widzenia udziałowców i akcjonariuszy ${ }^{24}$. Duża wartość miernika i jego regularny wzrost, w porównaniu z latami poprzednimi, są zjawiskami pożądanymi przez przedsiębiorstwo, gdyż sygnalizują polepszenie kondycji finansowej badanej jednostki gospodarczej ${ }^{25}$. Im wyższa wartość stopy zwrotu z kapitału, tym większe możliwości uzyskania wyższych dywidend i większy przyrost wartości akcji. Niski wskaźnik będzie zniechęcał do inwestowania $\mathrm{w}$ dane przedsiębiorstwo, gdyż taki rodzaj inwestycji jest mało opłacalny, a ponadto może wiązać się z zagrożeniem kontynuacji działalności jednostki gospodarczej.

W przypadku wskaźnika rentowności kapitałów własnych również nie istnieje optymalna wartość miernika. Podobnie jak w przypadku pozostałych klasycznych mierników rentowności wszystko zależy od profilu działalności przedsiębiorstwa, aczkolwiek wielkość wskaźnika będzie tym większa, im wyższy będzie poziom zysku oraz niższy udział kapitałów własnych w kapitałach danego podmiotu gospodarczego. Dokonując interpretacji zmiany tego wskaźnika należy zwrócić uwagę, czym są one spowodowane, gdyż mogą wynikać z wykorzystania chociażby kapitałów zapasowych.

Powyższe wskaźniki rentowności ROS, ROA i ROE zostaną wykorzystane przez autorkę $\mathrm{w}$ empirycznej części artykułu celem ich analizy w przekroju sektorowym dla polskich spółek publicznych notowanych na GPW.

\section{Rentowność spółek notowanych na GPW w Warszawie w latach 2006-2012 na przykładzie wybranych sektorów gospodarki}

\subsection{Opis organizacji badania}

Przedmiotem badania empirycznego była analiza rentowności spółek publicznych, należących do wybranych sektorów, notowanych na Warszawskiej Giełdzie Papierów Wartościowych w latach 2006-2012.

$\mathrm{W}$ ramach badania sformułowano następujące pytania badawcze:

1. Czy rentowność zależy od branży, w której działają spółki?

2. Czy można zidentyfikować branże o wyższej i niższej rentowności?

${ }^{23}$ L. Bednarski, Analiza finansowa w przedsiębiorstwie, PWE, Warszawa 2007, s. 113.

${ }^{24}$ A. Ćwiąkała-Małys, W. Nowak, Zarys..., s. 113-114.

${ }^{25}$ P. Gołaszewski, P. Urbanek, E. Walińska, Analiza sprawozdań finansowych, Fundacja Rozwoju Rachunkowości w Polsce, Łódź 2001, s. 55-56. 
3. Czy kryzys finansowy znalazł odzwierciedlenie w rentowności polskich spółek publicznych?

W pracy postawiono następujące hipotezy badawcze:

H I. Rentowność uzależniona jest od branży, w której działają spółki publiczne;

H II. Kryzys finansowy wpłynął na znaczne pogorszenie rentowności spółek publicznych.

Grupę badawczą stanowiły polskie spółki publiczne z wybranych sektorów gospodarki notowane na Warszawskiej Giełdzie Papierów Wartościowych. Autorka dokonując wyboru grupy badawczej odrzuciła zarówno banki, jak i zakłady ubezpieczeń, gdyż sprawozdania finansowe obu tych podmiotów zgodnie $\mathrm{z}$ ustawą o rachunkowości ${ }^{26}$ różnią się zawartością $\mathrm{w}$ porównaniu ze sprawozdaniami sporządzanymi przez inne jednostki. Jednym z kryteriów branych pod uwagę była również liczebność branży. Ponadto autorka, dokonując ostatecznej selekcji, chciała przedstawić sytuację w odmiennych sektorach gospodarki. W tym celu zostały wybrane następujące sektory:

- budownictwo,

- informatyka,

- przemysł elektromaszynowy,

- przemysł spożywczy,

- media,

- handel hurtowy,

- handel detaliczny.

Na potrzeby badania stworzono bazę danych w programie Excel, która zawierała informacje pochodzące $\mathrm{z}$ jednostkowych sprawozdań finansowych spółek $^{27}$. Spółki publiczne mają obowiązek udostępniania na stronach internetowych swoich raportów rocznych, zawierających m.in. sprawozdania finansowe. Na tej podstawie obliczono wybrane wskaźniki rentowności.

Metodą badawczą wykorzystaną w niniejszym badaniu była analiza danych ujawnianych przez spółki publiczne.

W ramach badania przyjęto następujące założenia:

1. W przypadku spółek nierentownych, czyli takich, które osiągały ujemny wynik finansowy, przyjęto, że wskaźniki rentowności (ROS, ROA, ROE) wynoszą zero ${ }^{28}$.

2. Dla spółek mających ujemny kapitał własny nie oblicza się wskaźnika ROE i przyjmuje się jego wartość równą zero.

${ }^{26}$ Ustawa z dnia 29 września 1994 r. o rachunkowości, DzU, 2009, nr 152, poz. 1223, nr 157, poz. 1241, nr 165, poz. 1316; 2010, nr 47, poz. 278; 2011, nr 102, poz. 585.

${ }^{27} \mathrm{~W}$ przypadku, gdy spółka $\mathrm{z}$ danej branży sporządzała tylko sprawozdanie skonsolidowane nie została ona objęta badaniem.

${ }^{28}$ Zgodnie $\mathrm{z}$ wytycznymi zawartymi w literaturze przedmiotu nie interpretuje się ujemnych mierników rentowności, gdyż nie ma ona wówczas sensu ekonomicznego. 
3. Obliczając średnią wartość poszczególnych wskaźników rentowności dla wybranego sektora uwzględniono wszystkie spółki wchodzące w skład danego sektora.

W części empirycznej autorka zamiennie używa pojęć branża - sektor. Ilekroć w pracy pojawi się sformułowanie:

- średnia wartość - oznaczać to będzie średnią arytmetyczną wartość danego wskaźnika dla całego sektora,

- liczba spółek nierentownych - to liczba spółek, które osiągnęły ujemny wynik finansowy,

- liczna spółek z niewspółmiernie wysoką do branży rentownością - to liczba spółek, dla których dany wskaźnik rentowności kształtuje się powyżej $40 \%$,

- ROS - wskaźnik rentowności sprzedaży wyrażony stosunkiem wyniku finansowego netto do przychodów ze sprzedaży produktów, towarów i materiałów,

- ROA - wskaźnik rentowności majątku wyrażony stosunkiem wyniku finansowego netto do sumy aktywów,

- ROE - wskaźnik rentowności kapitału własnego wyrażony stosunkiem wyniku finansowego netto do kapitału własnego.

\subsection{Rentowność spółek notowanych na GPW - raport z badania}

Analizę rentowności rozpoczęto od analizy pierwszej wybranej branży - budownictwo (tabela 1). Biorąc pod uwagę wyniki niniejszego badania można stwierdzić, że na przestrzeni analizowanych lat mediana rentowności (sprzedaży, majątku i kapitałów własnych) spółek tej branży systematycznie maleje. Obserwuje się jedynie nieznaczny wzrost wielkości wskaźników rentowności w roku 2007 względem roku poprzedniego. Uzyskane wyniki świadczą o tym, że kryzys finansowy wpłynął na pogorszenie rentowności spółek publicznych sektora budownictwo. Spadek rentowności w tym sektorze jest spowodowany zwiększeniem się liczby spółek nierentownych (w roku 2007 - 1 spółka nierentowna, w 2008 - 3, w 2009 - 8, w 2010 - 6, w 2011 - 11, w 2012 - aż 16). Ponadto należy również zauważyć, że w branży tej występują spółki z niewspółmiernie wysoką w stosunku do branży rentownością kapitału własnego w latach 2006-2007. W przypadku pozostałych lat i innych wskaźników rentowności dla branży budownictwo występowanie takich spółek jest rzadkością. Można zaobserwować rozbieżności między średnią wartością a medianą dla poszczególnych wskaźników, które wynikają z występowania spółek z niewspółmiernie wysoką do branży rentownością oraz występowania spółek nierentownych. Mediana wskaźnika rentowności sprzedaży kształtuje się na poziomie $0,64-6,78 \%$, tymczasem średnia wartość tego wskaźnika to 4,91$10,57 \%$. Mediana rentowności majątku wynosi od 0,78 do $7,56 \%$, natomiast średnia od 1,53 do 8,24\%. Mediana kapitałów własnych kształtuje się od 2,38 do $16,50 \%$, średnia zaś od 4,81 do $20,88 \%$. 
Tabela 1. Rentowność polskich spółek publicznych z branży budownictwo w latach 2006-2012

\begin{tabular}{|c|c|c|c|c|c|c|c|c|}
\hline \multicolumn{9}{|c|}{ BUDOWNICTWO } \\
\hline & Wskaźnik & 2006 & 2007 & 2008 & 2009 & 2010 & 2011 & 2012 \\
\hline \multirow{3}{*}{$\begin{array}{l}\mathrm{R} \\
\mathrm{O} \\
\mathrm{S}\end{array}$} & $\begin{array}{l}\text { Średnia wartość } \\
(\mathrm{w} \%)\end{array}$ & 6,62 & 9,14 & 6,63 & 4,91 & 4,68 & 4,69 & 10,57 \\
\hline & Mediana (w \%) & 3,99 & 6,78 & 5,61 & 4,41 & 3,38 & 2,68 & 0,64 \\
\hline & $\begin{array}{l}\text { Liczba spółek z nie- } \\
\text { współmiernie wy- } \\
\text { soką do branży } \\
\text { rentownością }\end{array}$ & 0 & 1 & 0 & 0 & 0 & 0 & 1 \\
\hline \multirow{3}{*}{$\begin{array}{l}\mathrm{R} \\
\mathrm{O} \\
\mathrm{A}\end{array}$} & $\begin{array}{l}\text { Średnia wartość } \\
(\mathrm{w} \%)\end{array}$ & 7,55 & 8,24 & 6,84 & 5,46 & 3,96 & 3,63 & 1,53 \\
\hline & Mediana (w \%) & 5,60 & 7,56 & 5,21 & 5,00 & 3,78 & 3,00 & 0,78 \\
\hline & $\begin{array}{l}\text { Liczba spółek z nie- } \\
\text { współmiernie wy- } \\
\text { soką do branży } \\
\text { rentownością }\end{array}$ & 0 & 0 & 0 & 0 & 0 & 0 & 0 \\
\hline \multirow{4}{*}{$\begin{array}{l}\mathrm{R} \\
\mathrm{O} \\
\mathrm{E}\end{array}$} & $\begin{array}{l}\text { Średnia wartość } \\
(\mathrm{w} \%)\end{array}$ & 19,26 & 20,88 & 15,48 & 12,10 & 8,65 & 7,17 & 4,81 \\
\hline & Mediana (w \%) & 14,33 & 16,50 & 11,98 & 9,86 & 7,39 & 6,88 & 2,38 \\
\hline & $\begin{array}{l}\text { Liczba spółek z nie- } \\
\text { współmiernie wy- } \\
\text { soką do branży } \\
\text { rentownością }\end{array}$ & 6 & 5 & 1 & 1 & 0 & 0 & 0 \\
\hline & $\begin{array}{l}\text { Liczba spółek } \\
\text { o ujemnym kapi- } \\
\text { tale własnym }\end{array}$ & 3 & 1 & 0 & 0 & 0 & 1 & 4 \\
\hline \multicolumn{2}{|c|}{$\begin{array}{l}\text { Liczba spółek nierentow- } \\
\text { nych }\end{array}$} & 5 & 1 & 3 & 8 & 6 & 11 & 16 \\
\hline \multicolumn{2}{|c|}{ Liczba badanych spółek } & 33 & 36 & 36 & 36 & 36 & 36 & 35 \\
\hline
\end{tabular}

Źródło: opracowanie własne.

Istotnych spostrzeżeń dostarcza analiza rentowności sektora - informatyka (tabela 2). Obserwuje się regularny spadek mediany wszystkich trzech wskaźników rentowności od roku 2007, natomiast w roku 2010 nastąpiła poprawa tych wskaźników. Występowanie spółek z niewspółmiernie wysoką jak na tę branżę rentownością jest rzadkością. Spadek wartości wskaźników może być skutkiem kryzysu finansowego, który zaczął się latem 2007 r. W branży informatyka mediana dla wskaźnika rentowności sprzedaży kształtowała się na poziomie 1,82-7,24\%, mediana dla rentowności aktywów 2,26-5,94\%, natomiast mediana dla rentowności kapitału własnego - 2,92-10,29\%. W sektorze informatyka obserwuje się wzrost liczby spółek mających ujemny wynik finansowy w okresie 2008-2010. W roku 2008 spółki nierentowne stanowiły $21 \%$ wszystkim spółek, a w latach 2009 i 2010 - 33\%. 
Tabela 2. Rentowność polskich spółek publicznych z branży informatyka w latach 2006-2012

\begin{tabular}{|c|c|c|c|c|c|c|c|c|}
\hline \multicolumn{9}{|c|}{ INFORMATYKA } \\
\hline & Wskaźnik & 2006 & 2007 & 2008 & 2009 & 2010 & 2011 & 2012 \\
\hline \multirow{3}{*}{$\begin{array}{l}\mathrm{R} \\
\mathrm{O} \\
\mathrm{S}\end{array}$} & $\begin{array}{l}\text { Średnia wartość } \\
(\mathrm{w} \%)\end{array}$ & 11,41 & 14,18 & 5,30 & 8,03 & 70,68 & 9,23 & 10,02 \\
\hline & Mediana (w \%) & 7,24 & 6,09 & 2,89 & 1,82 & 3,02 & 2,95 & 3,30 \\
\hline & $\begin{array}{l}\text { Liczba spółek } \\
\text { z niewspółmiernie } \\
\text { wysoką do branży } \\
\text { rentownością }\end{array}$ & 1 & 1 & 0 & 2 & 2 & 1 & 3 \\
\hline \multirow{3}{*}{$\begin{array}{l}\mathrm{R} \\
\mathrm{O} \\
\mathrm{A}\end{array}$} & $\begin{array}{l}\text { Średnia wartość } \\
(\mathrm{w} \%)\end{array}$ & 9,77 & 5,93 & 4,16 & 3,49 & 4,09 & 4,59 & 4,25 \\
\hline & Mediana (w \%) & 5,94 & 5,15 & 3,80 & 2,26 & 3,34 & 2,87 & 3,38 \\
\hline & $\begin{array}{l}\text { Liczba spółek } \\
\text { z niewspółmiernie } \\
\text { wysoką do branży } \\
\text { rentownością }\end{array}$ & 1 & 0 & 0 & 0 & 0 & 0 & 0 \\
\hline \multirow{4}{*}{$\begin{array}{l}\mathrm{R} \\
\mathrm{O} \\
\mathrm{E}\end{array}$} & $\begin{array}{l}\text { Średnia wartość } \\
(\mathrm{w} \%)\end{array}$ & 17,71 & 9,38 & 58,56 & 62,39 & 6,05 & 6,72 & 5,86 \\
\hline & Mediana (w \%) & 10,29 & 7,13 & 5,84 & 2,92 & 4,68 & 3,48 & 5,54 \\
\hline & $\begin{array}{l}\text { Liczba spółek } \\
\text { z niewspółmiernie } \\
\text { wysoką do branży } \\
\text { rentownością }\end{array}$ & 3 & 0 & 1 & 1 & 0 & 0 & 0 \\
\hline & $\begin{array}{l}\text { Liczba spółek } \\
\text { o ujemnym kapi- } \\
\text { tale własnym }\end{array}$ & 0 & 1 & 0 & 1 & 1 & 0 & 1 \\
\hline \multicolumn{2}{|c|}{$\begin{array}{l}\text { Liczba spółek nieren- } \\
\text { townych }\end{array}$} & 3 & 3 & 6 & 10 & 10 & 4 & 8 \\
\hline \multicolumn{2}{|c|}{ Liczba badanych spółek } & 28 & 28 & 29 & 30 & 30 & 29 & 28 \\
\hline
\end{tabular}

Źródło: opracowanie własne.

Analiza mediany rentowności spółek publicznych należących do branży przemysł elektromaszynowy (tabela 3) pozwala na stwierdzenie, że zyskowność przedsiębiorstw $\mathrm{z}$ tego sektora regularnie spada względem roku poprzedniego od roku 2008, co może być konsekwencją kryzysu finansowego, którego początki można było zidentyfikować w Stanach Zjednoczonych w roku 2007. Można jednak zaobserwować polepszenie się wskaźników rentowności od roku 2011. Mediana wskaźnika rentowności sprzedaży kształtuje się na poziomie 4,27$8,84 \%$, natomiast miernika rentowności aktywów od 4,75 do 9,57\%. Mediana rentowności kapitału własnego spółek należących do tego sektora wynosi od 6,30 do $19,02 \%$. Ponadto należy podkreślić, że następuje wzrost liczby nierentownych spółek w tym sektorze (w roku 2006 - 1 spółka nierentowna, w 2007 i 2008 r. - 2 spółki, w 2009 i 2011 - 3 spółki, w 2010 - 5 spółek, w 2012 
- 2 spółki). Spółki charakteryzujące się niewspółmiernie wysoką rentownością występują sporadycznie w branży przemysł elektromaszynowy.

Tabela 3. Rentowność polskich spółek publicznych z branży przemysł elektromaszynowy w latach 2006-2012

\begin{tabular}{|c|c|c|c|c|c|c|c|c|}
\hline \multicolumn{9}{|c|}{ PRZEMYSŁ ELEKTROMASZYNOWY } \\
\hline & Wskaźnik & 2006 & 2007 & 2008 & 2009 & 2010 & 2011 & 2012 \\
\hline \multirow{3}{*}{$\begin{array}{l}\mathrm{R} \\
\mathrm{O} \\
\mathrm{S}\end{array}$} & Średnia wartość (w \%) & 10,97 & 14,07 & 9,57 & 9,51 & 6,73 & 11,21 & 12,47 \\
\hline & Mediana (w \%) & 8,04 & 8,84 & 5,03 & 4,27 & 4,80 & 6,42 & 8,59 \\
\hline & $\begin{array}{l}\text { Liczba spółek z nie- } \\
\text { współmiernie wysoką } \\
\text { do branży rentownością }\end{array}$ & 1 & 2 & 1 & 2 & 0 & 1 & 2 \\
\hline \multirow{3}{*}{$\begin{array}{l}\mathrm{R} \\
\mathrm{O} \\
\mathrm{A}\end{array}$} & Średnia wartość (w \%) & 11,89 & 10,43 & 6,53 & 5,57 & 4,73 & 8,40 & 7,78 \\
\hline & Mediana (w \%) & 9,57 & 8,91 & 5,68 & 4,75 & 4,92 & 4,99 & 6,25 \\
\hline & $\begin{array}{l}\text { Liczba spółek z nie- } \\
\text { współmiernie wysoką } \\
\text { do branży rentownością }\end{array}$ & 0 & 0 & 0 & 0 & 0 & 1 & 0 \\
\hline \multirow{4}{*}{$\begin{array}{l}\mathrm{R} \\
\mathrm{O} \\
\mathrm{E}\end{array}$} & Średnia wartość (w \%) & 19,78 & 15,60 & 9,94 & 8,04 & 6,76 & 12,63 & 11,30 \\
\hline & Mediana (w \%) & 19,02 & 12,70 & 7,63 & 6,49 & 6,30 & 9,45 & 8,93 \\
\hline & $\begin{array}{l}\text { Liczba spółek z nie- } \\
\text { współmiernie wysoką } \\
\text { do branży rentownością }\end{array}$ & 4 & 1 & 0 & 0 & 0 & 1 & 0 \\
\hline & $\begin{array}{l}\text { Liczba spółek o ujem- } \\
\text { nym kapitale własnym }\end{array}$ & 0 & 0 & 0 & 0 & 0 & 0 & 0 \\
\hline \multicolumn{2}{|c|}{$\begin{array}{l}\text { Liczba spółek nierentow- } \\
\text { nych }\end{array}$} & 1 & 2 & 2 & 3 & 5 & 3 & 1 \\
\hline \multicolumn{2}{|c|}{ Liczba badanych spółek } & 25 & 26 & 26 & 26 & 27 & 26 & 25 \\
\hline
\end{tabular}

Źródło: opracowanie własne.

Kolejną branżą, której rentowność została poddana badaniu, jest przemysł spożywczy (tabela 4). Na podstawie mediany rentowności ROS, ROA i ROE można sformułować wniosek, że w latach 2006-2012 z roku na rok obserwuje się spadek rentowności spółek $\mathrm{z}$ tego sektora (występują sporadyczne wahania wzrostu rentowności z roku na rok, jednak są one niewielkie). Zarówno mediana wskaźnika rentowności sprzedaży, jak i rentowności majątku kształtowała się odpowiednio na poziomie $0,86-4,80 \%$ i $1,13-4,84 \%$. Miara ta dla wskaźnika rentowności kapitału własnego osiągnęła natomiast wartości w przedziale od 1,23 do $9,71 \%$. Spółki nierentowne w tym sektorze pojawiły się dopiero w roku 2008 i stanowiły odpowiednio 35\% wszystkich spółek z tego sektora w roku $2008,30 \%$ - w roku 2009, 27\% - w roku 2010, 30\% - w roku 2011 i 32\% - w roku 2012. Tymczasem spółki charakteryzujące się bardzo wysoką rentownością względem swojej branży występowały sporadycznie (maksymalnie $2 \mathrm{w}$ danym roku). 
Tabela 4. Rentowność polskich spółek publicznych z branży przemysł spożywczy w latach 2006-2012

\begin{tabular}{|c|c|c|c|c|c|c|c|c|}
\hline \multicolumn{9}{|c|}{ PRZEMYSŁ SPOŻYWCZY } \\
\hline & Wskaźnik & 2006 & 2007 & 2008 & 2009 & 2010 & 2011 & 2012 \\
\hline \multirow[b]{3}{*}{$\begin{array}{l}\mathrm{R} \\
\mathrm{O} \\
\mathrm{S}\end{array}$} & $\begin{array}{l}\text { Średnia wartość } \\
(\mathrm{w} \%)\end{array}$ & 12,30 & 10,53 & 14,43 & 9,06 & 1268,34 & 17,70 & 2705,88 \\
\hline & Mediana (w \%) & 4,80 & 3,41 & 2,26 & 2,01 & 1,91 & 0,86 & 1,65 \\
\hline & $\begin{array}{l}\text { Liczba spółek } \\
\text { z niewspółmier- } \\
\text { nie wysoką do } \\
\text { branży rentowno- } \\
\text { ścią }\end{array}$ & 1 & 1 & 1 & 1 & 2 & 2 & 2 \\
\hline \multirow[b]{3}{*}{$\begin{array}{l}\mathrm{R} \\
\mathrm{O} \\
\mathrm{A}\end{array}$} & $\begin{array}{l}\text { Średnia wartość } \\
(\mathrm{w} \%)\end{array}$ & 6,37 & 7,49 & 3,24 & 3,63 & 3,25 & 3,03 & 2,90 \\
\hline & Mediana (w \%) & 4,84 & 4,37 & 1,31 & 1,45 & 1,71 & 1,62 & 1,13 \\
\hline & $\begin{array}{l}\text { Liczba spółek } \\
\text { z niewspółmier- } \\
\text { nie wysoką do } \\
\text { branży rentowno- } \\
\text { ścią }\end{array}$ & 0 & 1 & 0 & 0 & 0 & 0 & 0 \\
\hline \multirow{4}{*}{$\begin{array}{l}\mathrm{R} \\
\mathrm{O} \\
\mathrm{E}\end{array}$} & $\begin{array}{l}\text { Średnia wartość } \\
(\mathrm{w} \%)\end{array}$ & 11,56 & 14,77 & 7,53 & 7,92 & 6,86 & 8,95 & 8,50 \\
\hline & Mediana (w \%) & 9,71 & 8,25 & 2,02 & 2,39 & 2,63 & 3,01 & 1,23 \\
\hline & $\begin{array}{l}\text { Liczba spółek } \\
\text { z niewspółmier- } \\
\text { nie wysoką do } \\
\text { branży rentowno- } \\
\text { ścią }\end{array}$ & 0 & 2 & 1 & 1 & 1 & 1 & 1 \\
\hline & $\begin{array}{l}\text { Liczba spółek } \\
\text { o ujemnym kapi- } \\
\text { tale własnym }\end{array}$ & 0 & 0 & 0 & 0 & 0 & 0 & 0 \\
\hline \multicolumn{2}{|c|}{$\begin{array}{l}\text { Liczba spółek } \\
\text { nierentownych }\end{array}$} & 0 & 0 & 7 & 6 & 6 & 6 & 6 \\
\hline \multicolumn{2}{|c|}{$\begin{array}{l}\text { Liczba badanych } \\
\text { spółek }\end{array}$} & 19 & 20 & 20 & 20 & 22 & 20 & 19 \\
\hline
\end{tabular}

Źródło: opracowanie własne.

Dokonując analizy rentowności spółek z branży media (tabela 5) można dostrzec spadek rentowności w roku 2008 względem roku poprzedniego. Taką samą tendencję spadkową można zaobserwować w roku następnym. Istotny wydaje się fakt, że wielkość mediany wskaźników rentowności ROS, ROA i ROE zwiększa się w roku 2011. Niska mediana wskaźnika rentowności sprzedaży, majątku i kapitału w roku 2012 (wartość wskaźnika wynosi niespełna 1\%) spowodowana jest występowaniem dużej liczby spółek nierentownych. Spółki te stanowią aż 40\% wszystkich spółek należących do tego sektora w roku 
2012. W latach 2006-2012 mediana dla wskaźnika ROS kształtowała się na poziomie $0,82-14,61 \%$, dla ROA $0,75-11,09 \%$, natomiast dla ROE 0,50 16,63\%. Dodatkowo, obserwuje się występowanie spółek osiągających ujemny wynik finansowy (od 2 do $6 \mathrm{w}$ każdym roku). Spółki charakteryzujące się ujemnym kapitałem własnym w branży media były rzadkością (maksymalnie jedna spółka $\mathrm{w}$ danym roku).

Tabela 5. Rentowność polskich spółek publicznych z branży media w latach 2006-2012

\begin{tabular}{|c|c|c|c|c|c|c|c|c|}
\hline \multicolumn{9}{|c|}{ MEDIA } \\
\hline & Wskaźnik & 2006 & 2007 & 2008 & 2009 & 2010 & 2011 & 2012 \\
\hline \multirow{3}{*}{$\begin{array}{l}\mathrm{R} \\
\mathrm{O} \\
\mathrm{S}\end{array}$} & $\begin{array}{l}\text { Średnia wartość } \\
(\mathrm{w} \%)\end{array}$ & 14,48 & 16,96 & 11,98 & 11,01 & 13,75 & 64,16 & 21,94 \\
\hline & Mediana (w \%) & 11,49 & 14,61 & 10,50 & 4,73 & 7,15 & 11,16 & 0,82 \\
\hline & $\begin{array}{l}\text { Liczba spółek } \\
\text { z niewspółmiernie } \\
\text { wysoką do branży } \\
\text { rentownością }\end{array}$ & 1 & 1 & 0 & 1 & 1 & 3 & 2 \\
\hline \multirow{3}{*}{$\begin{array}{l}\mathrm{R} \\
\mathrm{O} \\
\mathrm{A}\end{array}$} & $\begin{array}{l}\text { Średnia wartość } \\
(\mathrm{w} \%)\end{array}$ & 11,50 & 9,09 & 9,33 & 7,65 & 11,81 & 8,25 & 1409,53 \\
\hline & Mediana (w \%) & 11,09 & 7,99 & 6,17 & 2,71 & 4,32 & 5,06 & 0,75 \\
\hline & $\begin{array}{l}\text { Liczba spółek } \\
\text { z niewspółmiernie } \\
\text { wysoką do branży } \\
\text { rentownością }\end{array}$ & 0 & 0 & 0 & 0 & 2 & 0 & 1 \\
\hline \multirow{4}{*}{$\begin{array}{l}\mathrm{R} \\
\mathrm{O} \\
\mathrm{E}\end{array}$} & $\begin{array}{l}\text { Średnia wartość } \\
(\mathrm{w} \%)\end{array}$ & 19,58 & 27,34 & 17,59 & 14,25 & 16,94 & 11,59 & 7,23 \\
\hline & Mediana (w \%) & 16,63 & 10,83 & 9,34 & 3,39 & 5,65 & 6,72 & 0,50 \\
\hline & $\begin{array}{l}\text { Liczba spółek } \\
\text { z niewspółmiernie } \\
\text { wysoką do branży } \\
\text { rentownością }\end{array}$ & 3 & 3 & 2 & 2 & 3 & 0 & 1 \\
\hline & $\begin{array}{l}\text { Liczba spółek } \\
\text { o ujemnym kapi- } \\
\text { tale własnym }\end{array}$ & 1 & 0 & 0 & 0 & 1 & 1 & 1 \\
\hline \multicolumn{2}{|c|}{$\begin{array}{l}\text { Liczba spółek nieren- } \\
\text { townych }\end{array}$} & 3 & 2 & 3 & 4 & 3 & 2 & 6 \\
\hline \multicolumn{2}{|c|}{ Liczba badanych spółek } & 14 & 15 & 15 & 15 & 15 & 16 & 15 \\
\hline
\end{tabular}

Źródło: opracowanie własne. 
Rentowność spółek publicznych zaklasyfikowanych do branży handel hurtowy również została poddana analizie (tabela 6). Uzyskane wyniki pokazują, że zyskowność tych spółek maleje w latach 2007-2009. Tymczasem w roku 2010 następuje wzrost wskaźników rentowności i spadek w kolejnych latach. Zmiany te nie są jednak znaczne, gdyż sektor handel hurtowy charakteryzuje się niską rentownością. Niezwykle istotny jest fakt, że zaledwie jedna spółka w roku 2011 charakteryzowała się wskaźnikiem rentowności sprzedaży powyżej $40 \%$ i również jedna spółka w roku 2006 miała wskaźnik rentowności kapitału własnego powyżej $40 \%$. Można zatem stwierdzić, że w sektorze handel hurtowy nie występuje zjawisko występowania spółek z niewspółmiernie wysoką w stosunku do branży rentownością. Niemniej jednak w sektorze tym można zaobserwować negatywne zjawisko występowania dużej liczby spółek nierentownych począwszy od roku 2008. Niekorzystna tendencja utrzymuje się do roku 2012. Mediana rentowności sprzedaży dla analizowanego sektora w latach 2006-2012 wynosi od 0,94 do $2,38 \%$, tymczasem mediana rentowności majątku kształtuje się na poziomie $1,41-5,23 \%$. Większe różnice dostrzegane są $\mathrm{w}$ medianie rentowności kapitału własnego - wielkość tego wskaźnika waha się w przedziale od 2,59 do $16,28 \%$.

Tabela 6. Rentowność polskich spółek publicznych z branży handel hurtowy w latach 2006-2012

\begin{tabular}{|c|c|c|c|c|c|c|c|c|}
\hline \multicolumn{9}{|c|}{ HANDEL HURTOWY } \\
\hline & Wskaźnik & 2006 & 2007 & 2008 & 2009 & 2010 & 2011 & 2012 \\
\hline \multirow{3}{*}{$\begin{array}{l}\mathrm{R} \\
\mathrm{O} \\
\mathrm{S}\end{array}$} & Średnia wartość (w \%) & 3,46 & 3,37 & 1,96 & 2,49 & 2,74 & 50,15 & 2,83 \\
\hline & Mediana (w \%) & 2,38 & 2,02 & 1,07 & 1,00 & 1,39 & 0,98 & 0,94 \\
\hline & $\begin{array}{l}\text { Liczba spółek z nie- } \\
\text { współmiernie wysoką } \\
\text { do branży rentownością }\end{array}$ & 0 & 0 & 0 & 0 & 0 & 1 & 0 \\
\hline \multirow{3}{*}{$\begin{array}{l}\mathrm{R} \\
\mathrm{O} \\
\mathrm{A}\end{array}$} & Średnia wartość (w \%) & 6,04 & 5,07 & 3,06 & 3,40 & 3,44 & 3,86 & 2,76 \\
\hline & Mediana (w \%) & 5,23 & 3,92 & 1,98 & 2,05 & 3,57 & 2,73 & 1,41 \\
\hline & $\begin{array}{l}\text { Liczba spółek z nie- } \\
\text { współmiernie wysoką } \\
\text { do branży rentownością }\end{array}$ & 0 & 0 & 0 & 0 & 0 & 0 & 0 \\
\hline \multirow{4}{*}{$\begin{array}{l}\mathrm{R} \\
\mathrm{O} \\
\mathrm{E}\end{array}$} & Średnia wartość (w \%) & 15,86 & 11,65 & 6,72 & 6,77 & 7,64 & 8,08 & 5,81 \\
\hline & Mediana (w \%) & 16,28 & 10,17 & 4,71 & 4,54 & 7,99 & 7,05 & 2,59 \\
\hline & $\begin{array}{l}\text { Liczba spółek z nie- } \\
\text { współmiernie wysoką } \\
\text { do branży rentownością }\end{array}$ & 1 & 0 & 0 & 0 & 0 & 0 & 0 \\
\hline & $\begin{array}{l}\text { Liczba spółek o ujem- } \\
\text { nym kapitale własnym }\end{array}$ & 0 & 0 & 0 & 1 & 1 & 3 & 1 \\
\hline \multicolumn{2}{|c|}{ Liczba spółek nierentownych } & 2 & 1 & 6 & 7 & 7 & 7 & 7 \\
\hline \multicolumn{2}{|c|}{ Liczba badanych spółek } & 24 & 27 & 28 & 29 & 30 & 28 & 26 \\
\hline
\end{tabular}

Źródło: opracowanie własne. 
Ostatnią analizowaną branżą spółek publicznych notowanych na GPW w Warszawie pod względem rentowności jest handel detaliczny (tabela 7). Analizując obliczone mediany dla wskaźników rentowności można zaobserwować spadek ich wartości względem roku poprzedniego w latach 2007-2009. W roku 2010 następuje nieznaczna poprawa rentowności dla spółek sektora handel detaliczny. W kolejnych latach nie można dostrzec jednoznacznej zmiany kierunku zyskowności spółek w tym sektorze (w roku 2011 rentowność spada, a w roku 2012 rośnie). Zmiany wielkości wskaźników są jednak małe. Spółki z branży handel detaliczny charakteryzują się niską rentownością - mediana dla wskaźnika ROS waha się w przedziale $0,54-4,26 \%$, dla ROA $1,12-6,41 \%$, natomiast dla ROE 2,11-13,85\%. Ponadto w tej branży sporadycznym zjawiskiem jest występowanie spółek charakteryzujących się bardzo wysoką rentownością (powyżej 40\%). Warto jednak zauważyć, że spółki nierentowne w roku 2008 stanowią 37\% wszystkich spółek, w roku 2009 - 33\%, natomiast w roku 2011 aż 40\%.

Tabela 7. Rentowność polskich spółek publicznych z branży handel detaliczny w latach 2006-2012

\begin{tabular}{|c|c|c|c|c|c|c|c|c|}
\hline \multicolumn{9}{|c|}{ HANDEL DETALICZNY } \\
\hline & Wskaźnik & 2006 & 2007 & 2008 & 2009 & 2010 & 2011 & 2012 \\
\hline \multirow{3}{*}{$\begin{array}{l}\mathrm{R} \\
\mathrm{O} \\
\mathrm{S}\end{array}$} & $\begin{array}{l}\text { Średnia wartość } \\
(\mathrm{w} \%)\end{array}$ & 4,13 & 4,54 & 2,90 & 6,20 & 11,84 & 74,85 & 9,63 \\
\hline & Mediana (w \%) & 3,43 & 4,26 & 1,30 & 0,54 & 1,83 & 1,03 & 1,87 \\
\hline & $\begin{array}{l}\text { Liczba spółek z nie- } \\
\text { współmiernie wy- } \\
\text { soką do branży ren- } \\
\text { townością }\end{array}$ & 0 & 0 & 0 & 1 & 2 & 1 & 1 \\
\hline \multirow{3}{*}{$\begin{array}{l}\mathrm{R} \\
\mathrm{O} \\
\mathrm{A}\end{array}$} & $\begin{array}{l}\text { Średnia wartość } \\
(\mathrm{w} \%)\end{array}$ & 8,13 & 6,97 & 4,22 & 3,16 & 8,67 & 6,80 & 4,23 \\
\hline & Mediana (w \%) & 6,11 & 6,41 & 1,41 & 1,12 & 3,69 & 1,37 & 1,79 \\
\hline & $\begin{array}{l}\text { Liczba spółek z nie- } \\
\text { współmiernie wy- } \\
\text { soką do branży ren- } \\
\text { townością }\end{array}$ & 0 & 0 & 0 & 0 & 1 & 1 & 0 \\
\hline \multirow{4}{*}{$\begin{array}{l}\mathrm{R} \\
\mathrm{O} \\
\mathrm{E}\end{array}$} & $\begin{array}{l}\text { Średnia wartość } \\
(\mathrm{w} \%)\end{array}$ & 20,47 & 12,15 & 9,12 & 6,26 & 14,06 & 10,55 & 8,00 \\
\hline & Mediana (w \%) & 13,85 & 11,35 & 3,28 & 2,11 & 5,37 & 3,49 & 2,34 \\
\hline & $\begin{array}{l}\text { Liczba spółek z nie- } \\
\text { współmiernie wy- } \\
\text { soką do branży } \\
\text { rentownością }\end{array}$ & 4 & 0 & 0 & 0 & 1 & 1 & 0 \\
\hline & $\begin{array}{l}\text { Liczba spółek } \\
\text { o ujemnym kapitale } \\
\text { własnym }\end{array}$ & 1 & 1 & 1 & 2 & 1 & 0 & 0 \\
\hline \multicolumn{2}{|c|}{$\begin{array}{l}\text { Liczba spółek nierentow- } \\
\text { nych }\end{array}$} & 4 & 2 & 8 & 7 & 2 & 8 & 4 \\
\hline \multicolumn{2}{|c|}{ Liczba badanych spółek } & 21 & 21 & 22 & 21 & 21 & 20 & 17 \\
\hline
\end{tabular}

Źródło: opracowanie własne. 
W ramach badania empirycznego porównano również mediany wskaźników rentowności ROS, ROA i ROE dla wybranych sektorów spółek publicznych notowanych na GPW uzyskane dla poszczególnych sektorów z wynikami otrzymanymi dla całej grupy badawczej (tabela 8).

Tabela 8. Mediana wskaźników ROS, ROA, ROE dla polskich spółek publicznych według sektorów w latach 2006-2012 (w \%)

\begin{tabular}{|c|c|c|c|c|c|c|c|c|}
\hline & Sektor działalności & 2006 & 2007 & 2008 & 2009 & 2010 & 2011 & 2012 \\
\hline \multirow{8}{*}{$\begin{array}{l}\mathrm{R} \\
\mathrm{O} \\
\mathrm{S}\end{array}$} & budownictwo & 3,99 & 6,78 & 5,61 & 4,41 & 3,38 & 2,68 & 0,64 \\
\hline & informatyka & 7,24 & 6,09 & 2,89 & 1,82 & 3,02 & 2,95 & 3,30 \\
\hline & $\begin{array}{l}\text { przemysł elektro- } \\
\text { maszynowy }\end{array}$ & 8,04 & 8,84 & 5,03 & 4,27 & 4,80 & 6,42 & 8,59 \\
\hline & $\begin{array}{l}\text { przemysł spożyw- } \\
\text { czy }\end{array}$ & 4,80 & 3,41 & 2,26 & 2,01 & 1,91 & 0,86 & 1,65 \\
\hline & media & 11,49 & 14,61 & 10,50 & 4,73 & 7,15 & 11,16 & 0,82 \\
\hline & handel hurtowy & 2,38 & 2,02 & 1,07 & 1,00 & 1,39 & 0,98 & 0,94 \\
\hline & handel detaliczny & 3,43 & 4,26 & 1,30 & 0,54 & 1,83 & 1,03 & 1,87 \\
\hline & $\begin{array}{l}\text { dla wszystkich } \\
\text { spótek }\end{array}$ & 4,69 & 5,69 & 2,74 & 2,75 & 3,46 & 3,64 & 2,29 \\
\hline \multirow{8}{*}{$\begin{array}{l}\mathrm{R} \\
\mathrm{O} \\
\mathrm{A}\end{array}$} & budownictwo & 5,60 & 7,56 & 5,21 & 5,00 & 3,78 & 3,00 & 0,78 \\
\hline & informatyka & 5,94 & 5,15 & 3,80 & 2,26 & 3,34 & 2,87 & 3,38 \\
\hline & $\begin{array}{l}\text { przemysł elektro- } \\
\text { maszynowy }\end{array}$ & 9,57 & 8,91 & 5,68 & 4,75 & 4,92 & 4,99 & 6,25 \\
\hline & $\begin{array}{l}\text { przemysł spożyw- } \\
\text { czy }\end{array}$ & 4,84 & 4,37 & 1,31 & 1,45 & 1,71 & 1,62 & 1,13 \\
\hline & media & 11,09 & 7,99 & 6,17 & 2,71 & 4,32 & 5,06 & 0,75 \\
\hline & handel hurtowy & 5,23 & 3,92 & 1,98 & 2,05 & 3,57 & 2,73 & 1,41 \\
\hline & handel detaliczny & 6,11 & 6,41 & 1,41 & 1,12 & 3,69 & 1,37 & 1,79 \\
\hline & $\begin{array}{l}\text { dla wszystkich } \\
\text { spótek }\end{array}$ & 6,76 & 6,20 & 3,63 & 2,89 & 3,41 & 2,96 & 2,32 \\
\hline \multirow{8}{*}{$\begin{array}{l}\mathrm{R} \\
\mathrm{O} \\
\mathrm{E}\end{array}$} & budownictwo & 14,33 & 16,50 & 11,98 & 9,86 & 7,39 & 6,88 & 2,38 \\
\hline & informatyka & 10,29 & 7,13 & 5,84 & 2,92 & 4,68 & 3,48 & 5,54 \\
\hline & $\begin{array}{l}\text { przemysł elektro- } \\
\text { maszynowy }\end{array}$ & 19,02 & 12,70 & 7,63 & 6,49 & 6,30 & 9,45 & 8,93 \\
\hline & $\begin{array}{l}\text { przemysł spożyw- } \\
\text { czy }\end{array}$ & 9,71 & 8,25 & 2,02 & 2,39 & 2,63 & 3,01 & 1,23 \\
\hline & media & 16,63 & 10,83 & 9,34 & 3,39 & 5,65 & 6,72 & 0,50 \\
\hline & handel hurtowy & 16,28 & 10,17 & 4,71 & 4,54 & 7,99 & 7,05 & 2,59 \\
\hline & handel detaliczny & 13,85 & 11,35 & 3,28 & 2,11 & 5,37 & 3,49 & 2,34 \\
\hline & $\begin{array}{l}\text { dla wszystkich } \\
\text { spótek }\end{array}$ & 13,34 & 10,88 & 6,87 & 4,58 & 4,96 & 6,24 & 3,06 \\
\hline
\end{tabular}

Źródło: opracowanie własne.

Uzyskane na podstawie badania empirycznego wyniki pozwalają na sformułowanie ogólnych wniosków na temat kształtowania się rentowności spółek publicznych należących do wybranych sektorów. 
Z przeprowadzonej analizy wskaźników rentowności sprzedaży i majątku wynika, że rentowność jest zdecydowanie zależna od branży, w jakiej działa spółka. Można zatem stwierdzić, że występują sektory mniej i bardziej rentowne. Wszystkie analizowane branże można podzielić na trzy grupy:

- branże o wyższej rentowności - media i przemysł elektromaszynowy,

- branże o średniej rentowności - informatyka, budownictwo i przemysł spożywczy,

- branże o niskiej rentowności - handel detaliczny i handel hurtowy.

Analizując medianę rentowności sprzedaży i majątku w przekroju sektorowym można zauważyć generalną tendencję spadkową tych wskaźników w latach 2008-2009. W roku 2010 można zaobserwować wzrost wskaźników ROS i ROA dla większości analizowanych branż. Niestety tendencja wzrostowa nie utrzymuje się zbyt długo i w roku 2011 wielkości wskaźników znowu maleją.

Ponadto, analiza wyników rentowności kapitału własnego w przekroju sektorowym pozwala na stwierdzenie, że rentowność spółek publicznych sukcesywnie spada w latach 2006-2009. Dopiero w roku 2010 można zaobserwować poprawę wskaźnika rentowności ROE dla większości analizowanych sektorów (informatyka, przemysł spożywczy, media, handel hurtowy i handel detaliczny). Poprawa rentowności utrzymuje się również $\mathrm{w}$ kolejnym roku dla sektorów przemysł elektromaszynowy, przemysł spożywczy, media. Niestety w roku 2012 można dostrzec negatywne zjawisko spadku rentowności kapitału własnego we wszystkich analizowanych sektorach oprócz branży informatyka.

Istotne z punktu widzenia analizy rentowności wydaje się kształtowanie mediany wskaźnika ROS, ROA i ROE dla całej grupy badawczej, którą stanowiło 185 spółek ze wszystkich siedmiu analizowanych sektorów (wykres 1).

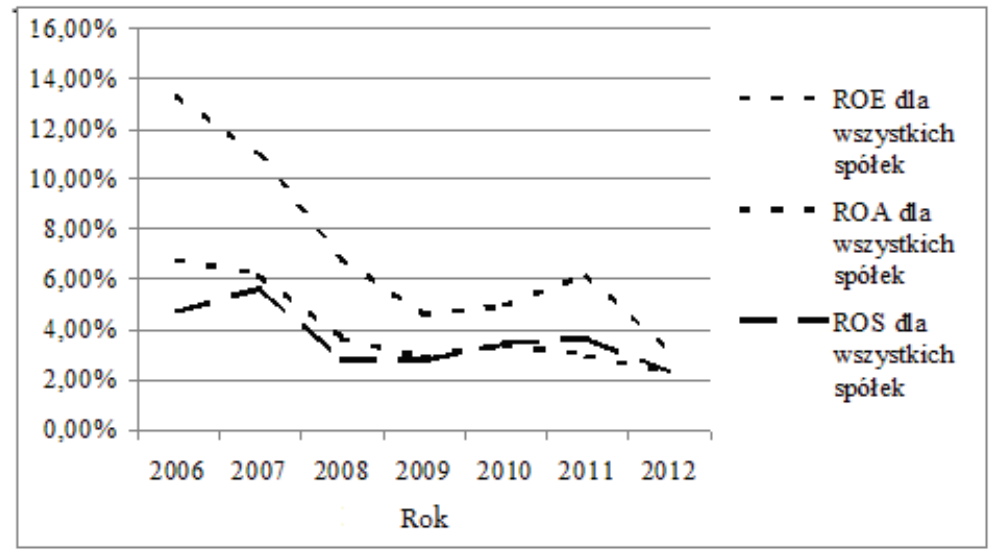

Wykres 1. Mediana rentowności dla wszystkich analizowanych spółek w latach 2006-2012 Źródło: opracowanie własne. 
Okazuje się, że wskaźniki rentowności w latach 2006-2009 wykazywały tendencję malejącą. Takie wyniki potwierdzają, iż kryzys finansowy, który został zapoczątkowany w roku 2007 w Stanach Zjednoczonych mógł mieć wpływ na kształtowanie się zyskowności polskich spółek publicznych.

Spowolnienie koniunktury gospodarczej spowodowało zmniejszenie popytu, co znalazło odzwierciedlenie w spadku przychodów ze sprzedaży. Jednocześnie przedsiębiorstwa, zwłaszcza w pierwszych latach kryzysu, nie zdołały zoptymalizować kosztów. W latach 2010-2011 widoczna jest jednak niewielka poprawa rentowności spółek publicznych, co może wynikać ze zwiększenia przychodów ze sprzedaży bądź z realizacji planów redukcji kosztów. Niestety rentowność spółek spada w roku 2012.

\section{Zakończenie}

Z punktu widzenia obecnej rzeczywistości gospodarczej zagadnienia związane $\mathrm{z}$ analizą finansową, a $\mathrm{w}$ szczególności $\mathrm{z}$ analizą rentowności, stają się niezwykle istotne. Współczesne przedsiębiorstwa funkcjonujące w warunkach gospodarki rynkowej wymagają umiejętnego i sprawnego zarządzania nimi. Od osób zarządzających zależy sukces przedsiębiorstwa, który możliwy jest do osiągnięcia po uprzedniej identyfikacji, a także realizacji zadań działalności podmiotu gospodarczego. Jednym z celów działalności przedsiębiorstw jest przetrwanie i utrzymanie się na rynku wśród wzrastającej konkurencji. W gospodarce wolnorynkowej fundamentalnym zadaniem przedsiębiorstw jest generowanie zysku oraz pomnażanie kapitału właścicieli. Niezwykle istotne jest, by we właściwy sposób oszacować efekty działania przedsiębiorstwa. Do pomiaru dokonań jednostki gospodarczej wykorzystuje się wskaźniki rentowności, które przedstawiają wypracowane przez przedsiębiorstwa zyski.

Celem niniejszego opracowania było przedstawienie teoretycznych i praktycznych aspektów dotyczących zagadnień związanych z rentownością. W pracy dokonana została analiza rentowności spółek publicznych działających w wybranych sektorach wyróżnionych na GPW.

W ramach badania empirycznego zweryfikowano pozytywnie obie hipotezy badawcze. A mianowicie, rentowność uzależniona jest od branży, w której działają spółki publiczne oraz kryzys finansowy znacząco wpłynął na pogorszenie rentowności spółek publicznych.

Można zatem wyróżnić branże, w skład których wchodzą spółki charakteryzujące się wysoką, jak i niską zyskownością. Dodatkowo należy zauważyć, że obserwuje się stopniowy spadek rentowności spółek publicznych od roku 2007, co odzwierciedla w dużej mierze sytuację finansową całego rynku. Uzyskane wyniki potwierdzają, że kryzys finansowy zapoczątkowany w roku 2007 w Stanach Zjednoczonych mógł mieć wpływ na kształtowanie się rentowności polskich spółek publicznych. Rentowność spółek poprawia się w okresie 2010-2011. 


\section{Literatura}

Bednarski L., Analiza finansowa w przedsiębiorstwie, PWE, Warszawa 2007.

Bednarski L., Analiza sytuacji majątkowo-finansowej przedsiębiorstwa, [w:] E. Walińska (red.), Meritum. Rachunkowość. Rachunkowość i sprawozdawczość finansowa, Wolters Kluwer business, Warszawa 2007.

Berman K., Knight J., Case J., Inteligencja finansowa. Co kryja liczby. Przewodnik menedżera, Helion, Gliwice 2007.

Ćwiąkała-Małys A., Nowak W., Zarys metodologiczny analizy finansowej, Wyd. UWr, Wrocław 2005.

Dynus M., Kołosowska B., Prewysz-Kwitno P., Analiza finansowa przedsiębiorstwa, TNOiK, Toruń 2005.

Gabrusewicz W., Podstawy analizy finansowej, PWE, Warszawa 2002.

Gad J., Rachunkowość w procesie nadzoru w spótkach publicznych, Wyd. UŁ, Łódź 2011.

Gołaszewski P., Urbanek P., Walińska E., Analiza sprawozdań finansowych, Fundacja Rozwoju Rachunkowości w Polsce, Łódź 2001.

Konopoczak K., Sieradzki R., Wiernicki M., Kryzys na światowych rynkach finansowych - wplyw na rynek finansowy w Polsce oraz implikacje dla sektora realnego, „Bank i Kredyt” 2010, nr 41 (6).

Kopczyńska L., Analiza sytuacji majątkowo-finansowej przedsiębiorstwa, [w:] E. Walińska (red.), Meritum. Rachunkowość. Rachunkowość i sprawozdawczość finansowa, Wolters Kluwer business, Warszawa 2007.

Kopczyńska L., Ocena kondycji finansowej przedsiębiorstwa, [w:] W. Walczak (red.), Analiza finansowa w zarządzaniu wspótczesnym przedsiębiorstwem, Difin, Warszawa 2007.

Kopczyńska L., Tradycyjne metody analizy rentowności, [w:] E. Walińska (red.), Meritum. Rachunkowość. Rachunkowość i sprawozdawczość finansowa 2006, Dom Wydawniczy, Warszawa 2006.

Nowak E., Analiza sprawozdań finansowych, PWE, Warszawa 2008.

Sierpińska M., Analiza sytuacji finansowej przedsiębiorstwa, [w:] M. Sierpińska, T. Jachna (red.), Metody podejmowania decyzji finansowych. Analiza przykładów i przypadków, Wyd. Nauk. PWN, Warszawa 2007.

Stępień K., Rentowność a wyptacalność przedsiębiorstw, Difin, Warszawa 2008.

Urbanek P., Kryzys finansowy a polityka wynagradzania menedżerów, [w:] P. Urbanek (red.), Nadzór korporacyjny w warunkach kryzysu gospodarczego, Wyd. UŁ, Łódź 2010.

Ustawa z dnia 29 września 1994 r. o rachunkowości, DzU, 2009, nr 152, poz. 1223; nr 157, poz. 1241 ; nr 165, poz. $1316 ; 2010$, nr 47, poz. 278; 2011, nr 102, poz. 585.

\section{Streszczenie}

Celem pracy jest dokonanie wielopłaszczyznowej analizy rentowności spółek publicznych działających na GPW, z uwzględnieniem sektorów działalności. Artykuł ma charakter teoretyczno-empiryczny. Grupę badawczą stanowiły spółki publiczne notowane na Warszawskiej Giełdzie Papierów Wartościowych, wchodzące w skład następujących sektorów: budownictwo, informatyka, przemysł elektromaszynowy, przemysł spożywczy, media, handel hurtowy i handel detaliczny. Do badania zostały wykorzystane informacje z raportów rocznych spółek publicznych (przede wszystkim sprawozdań finansowych), które są publikowane na stronach internetowych poszczególnych spółek. Metodą badawczą wykorzystaną w niniejszym badaniu była analiza danych ujawnianych przez spółki publiczne wchodzące w skład grupy badawczej. 


\section{Summary}

\section{PROFITABILITY OF POLISH PUBLIC COMPANIES LISTED ON THE WARSAW STOCK EXCHANGE: SECTOR ANALYSIS}

The objective of this paper is to conduct multifaceted analysis of the profitability of public companies operating on the Warsaw Stock Exchange with regard to the sectors of activity. This paper is of a theoretical and empirical nature. The study group were public companies listed on the Warsaw Stock Exchange, in the following sectors: construction, information technology, electrical engineering industry, food industry, media, wholesale and retail. The study used information from the annual reports of public companies (especially financial statements) which are published on the websites of individual companies. The analysis of data disclosed by public companies included in the research group was a research method used in the present study. 